\title{
Marine Administration and Spatial Data Infrastructure
}

\author{
Lisa Strain ${ }^{1}$, Abbas Rajabifard ${ }^{2}$ and Ian Williamson ${ }^{3}$ \\ ${ }^{1}$ M.Sc. Candidate \\ Email: lstrain@sunrise.sli.unimelb.edu.au \\ ${ }^{2}$ Deputy Director \\ Email: abbas.r@unimelb.edu.au \\ ${ }^{3}$ Director \\ Email: ianpw@unimelb.edu.au \\ Centre for Spatial Data Infrastructures and Land Administration
Department of Geomatics, The University of Melbourne, Victoria 3010, Australia
}

\begin{abstract}
This paper reviews the emergence of the spatial dimension of marine and coastal zone administration, and examines several initiatives around the world that contribute to this idea. Spatial data has been recognised as an important resource to improve decision-making and resource management in both the land and marine environments in terms of sustainable development. Many countries are developing Spatial Data Infrastructures (SDIs) to improve access and sharing of spatial data, however most of these initiatives stop at the coastline. Recently global and regional activities such as the $3^{\text {rd }}$ United Nations Convention on the Law of the Sea (UNCLOS) and the Sustainable Development Strategy for the Seas of East Asia (SDS-SEA) have brought to international attention the importance of effective administration of the marine and coastal environments.
\end{abstract}

Keywords: marine environment, spatial data infrastructures, marine cadastre

\section{Introduction}

The concepts of marine SDI, marine cadastre and marine spatial planning have all emerged recently in response to a global realisation of the need to improve management and administration of the marine environment. The underlying theme of these initiatives is the importance of including a spatial dimension in marine administration. This paper introduces and discusses the marine SDI concept, giving practical examples of this concept and related development from countries including 
USA, Canada, and Australia as well as global and regional examples. It also examines the issues involved in marine SDI development and the possible future direction of marine SDI. The effort is now directed towards finding a common approach from these initiatives and defining common terminology to improve management/ administration not only at a national level, but also regionally and globally.

Until recently management and administration tools were focussed mainly on the terrestrial environment. Within this environment it has been established that spatial information aids in decision making for land management and administration [1]. Frameworks such as spatial data infrastructures (SDIs) have been developed that allow access and sharing of spatial data. Many countries are implementing these frameworks at national, state and local levels, however most of these initiatives stop at the coastline. The need for access to spatial data for improved decision-making and management does not stop at the coastline.

Humankind is extremely reliant on the oceans, as a source of food and raw materials, as a climate regulator, for transportation, for disposal of waste products, and for recreation. According to the UN Atlas of the Oceans ${ }^{1}$ approximately $44 \%$ of the worlds population live within $150 \mathrm{~km}$ of the coast and this is likely to increase. The marine environment provides immense opportunity in terms of economic potential, with activities such as shipping, oil and gas mining, fishing and aquaculture. The $3^{\text {rd }}$ United Nations Convention on the Law of the Sea (UNCLOS) increases this potential with the ability of a coastal state to extend its maritime jurisdiction to the edge of the continental shelf. With this increased area however, comes increased responsibility for environmental protection. Therefore there has been increased global interest in managing the world's coasts and oceans in terms of sustainable development.

\section{Marine and Coastal Administration}

The first ocean management/ administration document 'Mare Liberum’ proclaimed international freedom of the seas. This recognised the oceans as a common resource available for exploitation by all, except for the area that could be protected from the coastline. With the industrial revolution and World Wars I and II, technology for

\footnotetext{
${ }^{1}$ www.oceansatlas.org
} 
exploring and mapping the oceans and sea floor improved, leading to a greater recognition of the economic potential provided by the marine environment. In 1945 the USA claimed resources in the continental shelf adjacent to the coastline, causing other countries to lodge similar claims and causing disagreement over the nature and extent of boundaries that a country was allowed [2]. There was recognition that an international agreement or policy was needed that documented the marine jurisdiction of a country.

UNCLOS III highlights the need for better management of the Worlds oceans environmentally and socially, as well as economically. It also specified marine jurisdictional boundaries, and their associated rights, for a coastal state. Since UNCLOS III there has been activity worldwide on marine management focussing on sustainable development (WSSD 2002, SDS-SEA 2003), boundary definition (at the University of New Brunswick marine cadastre meeting in Canada 2003) and Integrated Coastal Management (ICM) (CZAP 2004). There has also been improvement in information and communication technology, which is globally driving the exchange and sharing of data and information. It is just recently that these ideas are beginning to come together (Permanent Committee on GIS Infrastructure for Asia and the Pacific Working Group 3 (PCGIAP WG 3) workshop on Administering the Marine Environment - The Spatial Dimension, Malaysia 2004) as countries begin to think about marine administration and spatial data management. Figure 1 shows this evolving human attitude towards the marine environment. 


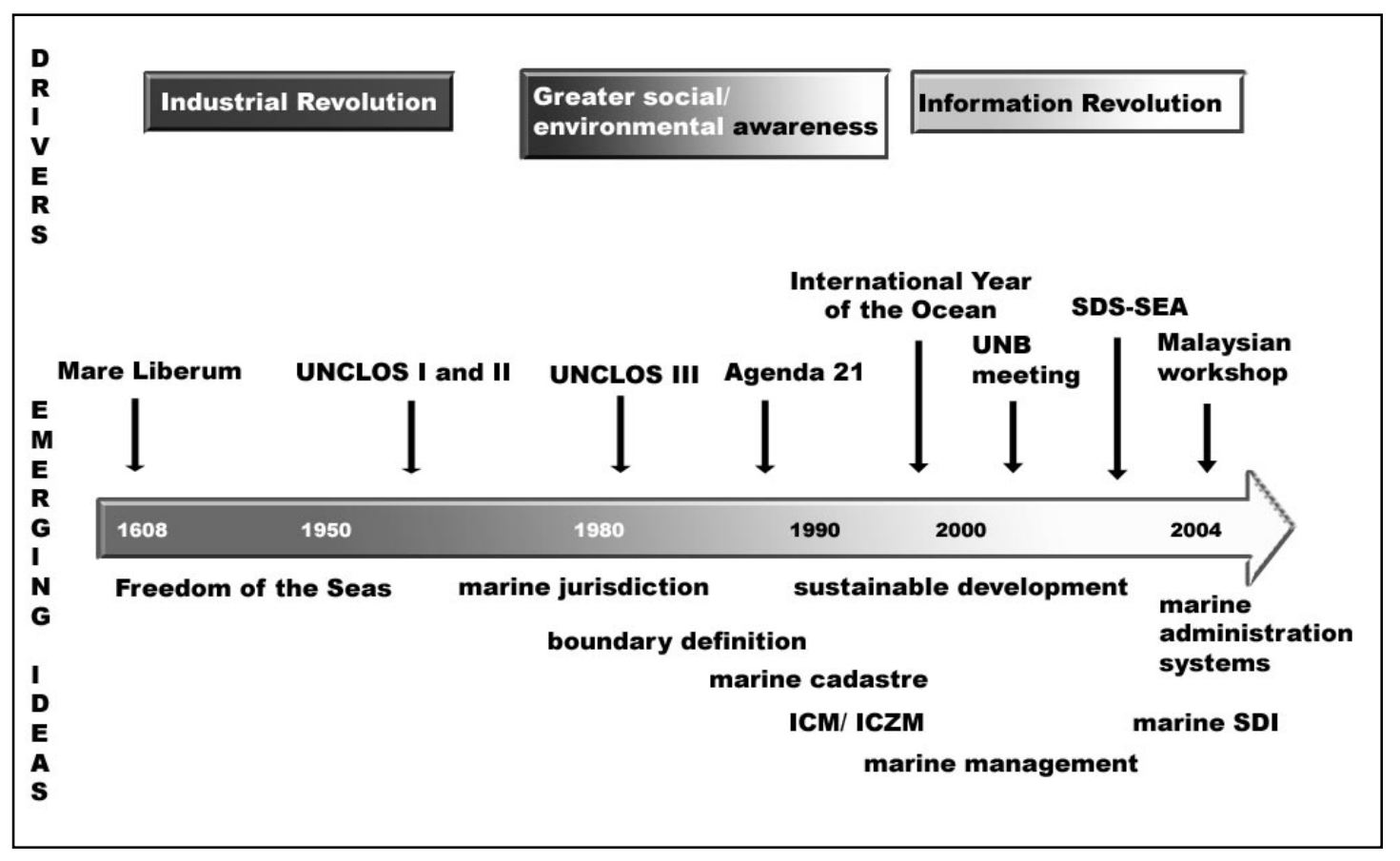

Figure 1: The development of marine administration

Despite the number of initiatives, marine and coastal areas are still poorly managed. Current marine and coastal administration has been described as 'neither effective, nor sustainable [3]. There are many different organisations, activities, legislative frameworks, international agreements and conventions, stakeholders and industries that are involved in marine management and administration of marine resources. Figure 2 gives an example of these different activities, and the some of the supporting framework such as marine policies, legislation, and planning.

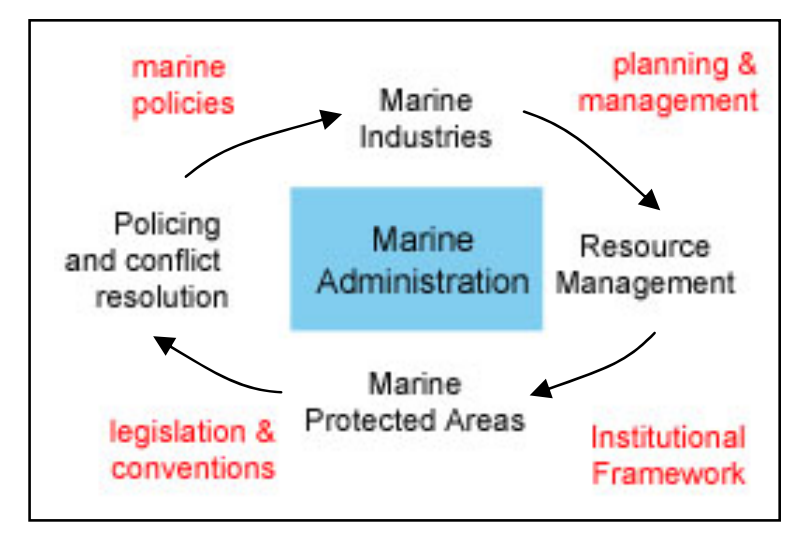

Figure 2: Marine Administration

One part of managing and administrating these activities is having access to relevant spatial data and information concerning the area. Within many of the initiatives shown in figure 1 the 
need for improved access to spatial information is recognised. For example from ICZM Doody [4] states:

$$
\begin{gathered}
\text { Data }+ \text { Context }=\text { Information } \\
\text { Information }+ \text { Analysis }=\text { Understanding } \\
\text { Understanding }+ \text { Management }=\text { Possibility of sustainable action. }
\end{gathered}
$$

Figure 2 showed some of the activities that are involved in marine and coastal zone administration. Each of these will require spatial data and information such as tide charts, bathymetry, climate, sea surface temperatures and currents, living and non-living resources, other property rights in the area, legislation, protected areas, international and national conventions. Having access to this spatial information is regarded as essential or important to the majority of stakeholders in the marine and coastal environments [5], however these people often report problems with accessing, sharing and using spatial data related to these areas.

The difficulty in accessing and using spatial data in the marine environment has been well documented. It was recognised by the CSIRO [6] in a proposed marine data policy, which states 'present users of ocean data are faced with a confusing array of datasets and data formats'. In a questionnaire conducted by the marine cadastre group at the University of Melbourne in 2003 the main problems that were highlighted in the responses were to do with accessibility, availability and applicability of marine spatial data [5]. This questionnaire was followed with industry consultation of stakeholders involved in many aspects of marine management in 2004. Again many responses included the need for improved sharing and standardisation of spatial data and metadata across organisations and levels of government [7]. At several presentations at CZAP 2004 (see [8], [9]) the importance of spatial information in ICM and coastal planning and development was noted along with the difficulty of coordinating, managing and sharing data at all levels. CSIRO [6] also noted that 'this has resulted in additional costs to the nation through duplication of effort, poor decisions and lost opportunities.' There is clearly an opportunity for improving management of the marine and coastal environment through better access and sharing of spatial information (see figure 3). 


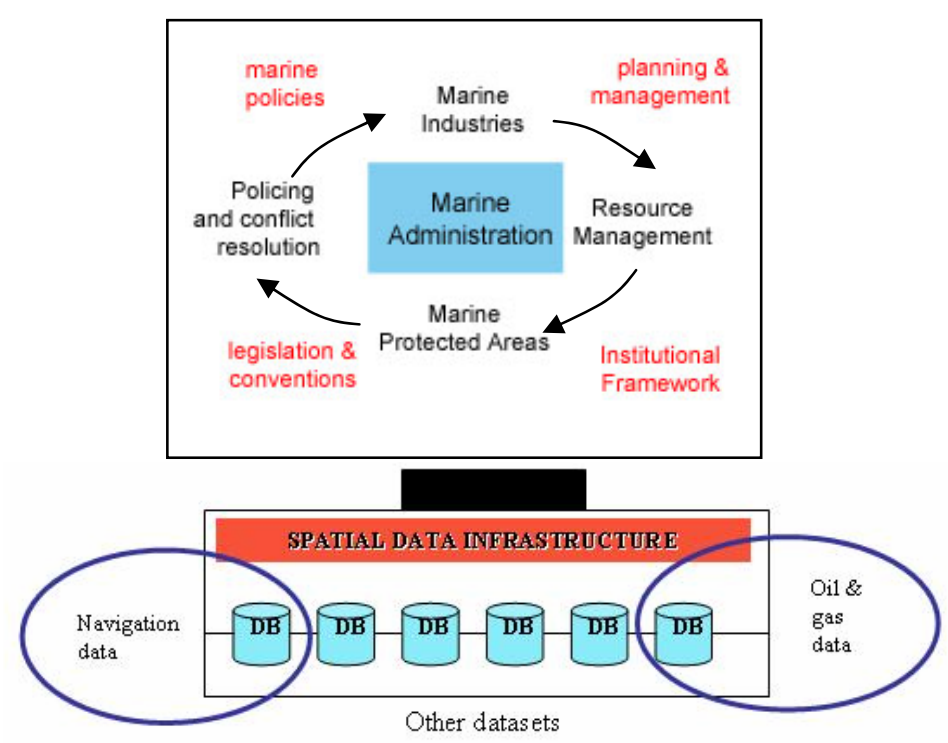

Figure 3: SDI in marine administration

Figure 3 describes the potential of an SDI to support access and sharing of marine spatial data. A marine SDI would sit between the administration/ management activities and the data, allowing any user access to appropriate data to support their needs, and allowing data to be collected once and used many times. This idea was supported at the UN-PCGIAP workshop on Administering the Marine Environment [10] that recommended that a coastal state in the Asia-Pacific region with an extensive marine jurisdiction should include a marine dimension in its National SDI initiative as part of its responsibilities under UNCLOS.

\section{Spatial Data Infrastructure - An Enabling Platform}

It is increasingly being recognised that spatial information is one of the most critical elements underpinning decision making for many disciplines. Spatial information provides a spatial/ geographic context to planning, management, and resource allocation allowing a better understanding of, and thus better management of an area. In response many countries around the world are developing SDI as a way to better manage and share their spatial data assets [11].

An SDI is a framework or system that facilitates the exchange and sharing of spatial data between people. It can be described as the underlying infrastructure, often in the 
form of policies, standards and access networks that allows data to be shared between and within organisations, states or countries. It has been likened to road or rail infrastructure, which supports transport over land, and comprises roads as well as the rules, maintenance policies, and jurisdictional rights to them. SDI is comprised of policies, standards and procedures under which organisations and technologies interact to foster more efficient use, management and production of geospatial data' [12]. Some of the benefits of developing SDI are: improved access to data, reduced duplication of effort in collecting and maintaining data, better availability of data and interoperability between datasets. Figure 4 shows the components of SDI that link people to data: the standards, policies and access networks.

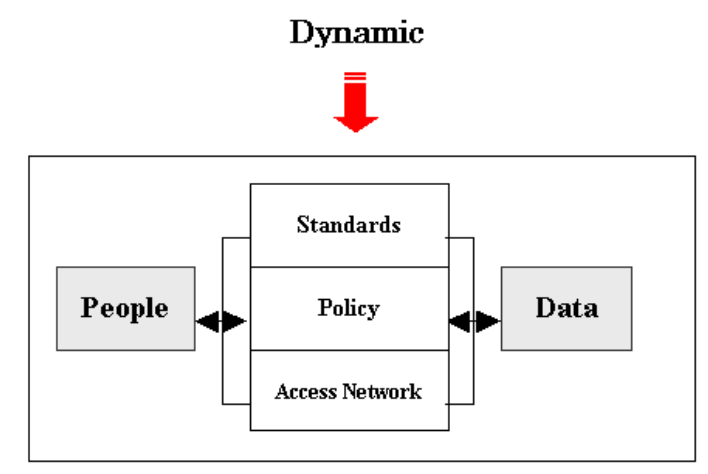

Figure 4: Components of SDI [13]

The SDI components will be discussed in detail later within the context of the marine environment. It is important to note that the concept is dynamic, in that it provides an ability to be updated with changing technology or human attitudes, or with the need for including new environments. There has been research worldwide into the SDI components and the methods for linking people to data, but these have mainly described the application of these components in the terrestrial environment. The next section discusses initiatives in the spatial dimension of marine administration from around the World, and the relationship between these and SDI.

\section{Marine SDI}

While the concept of marine SDI is relatively new, the idea of supporting marine and coastal management through better access to spatial data or information is more established. Several countries and different jurisdictions are trying to improve their 
marine management through improving the accessibility and availability of spatial data. Often while these initiatives are not labelled 'SDI' they share some of the objectives and concepts of SDI. The table below outlines the objectives and the practical examples, using the SDI components from Figure 4, for some of these initiatives. It also gives an overview of the aim of the Marine SDI initiative within in each jurisdiction. Borrero in the SDI cookbook [14] states that when developing SDI the following areas need to be considered: definition, objectives, principles, rules and responsibilities, coordination, policies and guidelines. These are similar to the SDI components from and so the table below uses the SDI components to examine the methods used by each country to achieve their objectives.

Comparison between different initiatives shows that each has different aims and ideas, responding to different cultures, levels of development and user needs. At the global and regional levels this difference needs to be considered, resulting in more general aims and initiatives.

\begin{tabular}{|c|c|}
\hline Country & Marine Administration \\
\hline Canada & 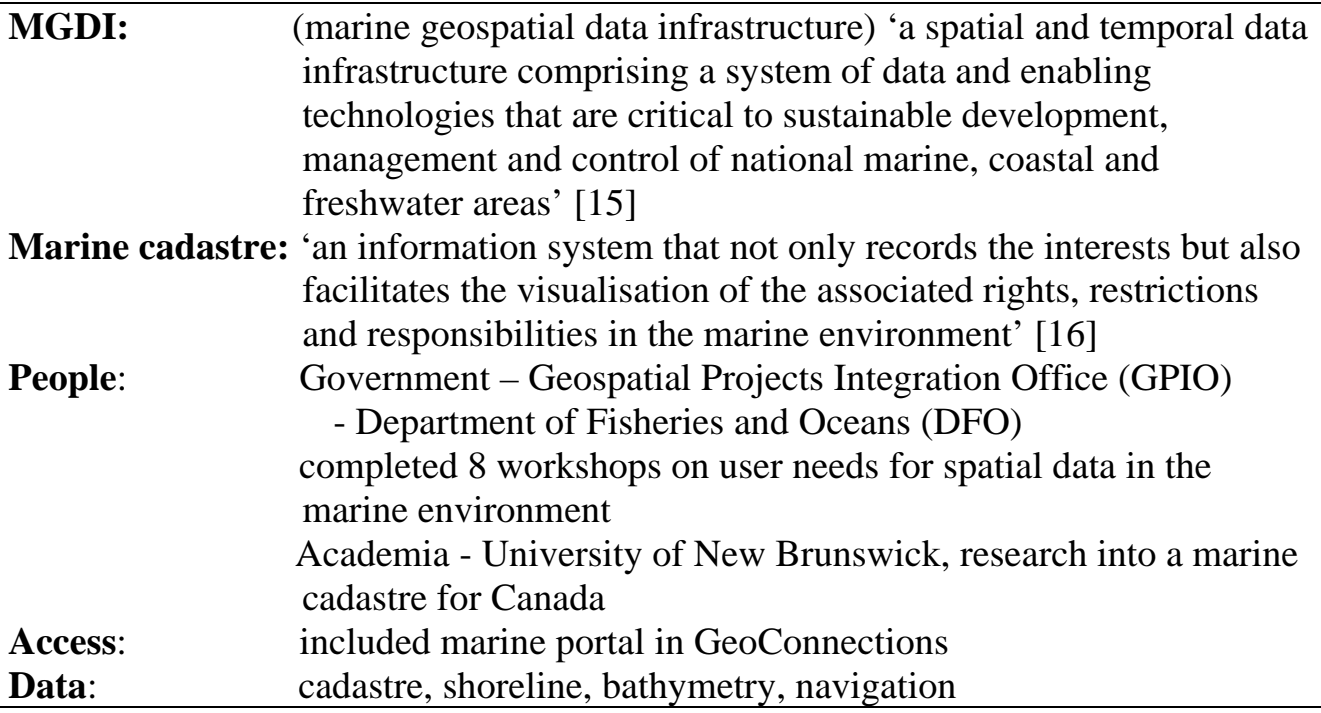 \\
\hline USA & 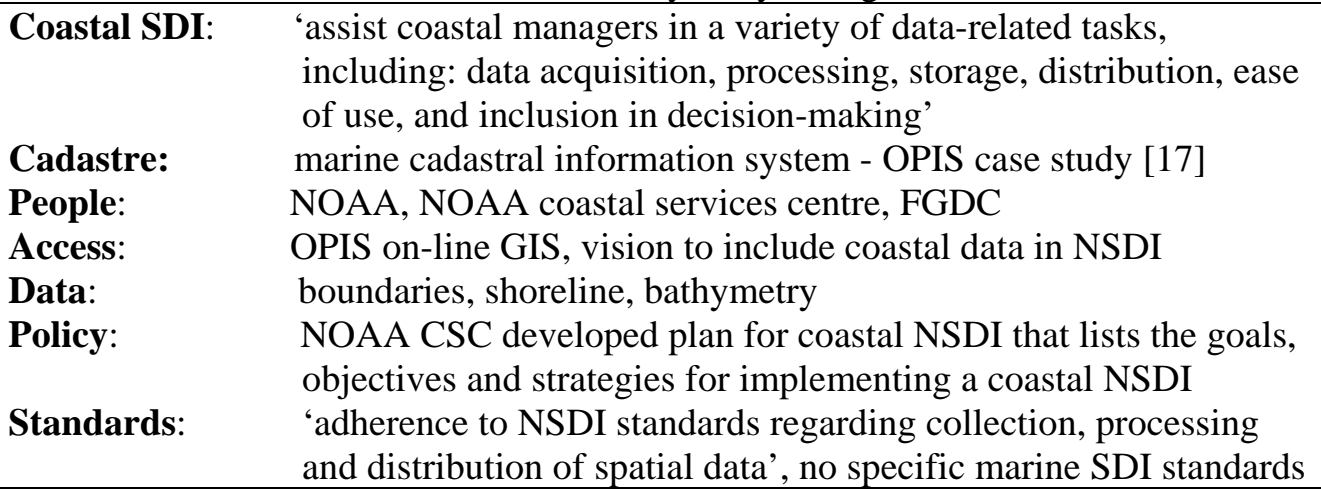 \\
\hline Australia & $\begin{array}{ll}\text { Marine SDI: } & \text { 'an Internet-based, customer focussed view into data and } \\
& \text { information of interest to users of the marine environment [18]' } \\
\text { Marine Cadastre: 'describe, visualise and realise rights, restrictions and } & \text { responsibilities in the marine environment [19], }\end{array}$ \\
\hline
\end{tabular}




\begin{tabular}{|c|c|c|}
\hline & $\begin{array}{l}\text { Access: } \\
\text { Data: } \\
\text { Policy: } \\
\text { Standards: }\end{array}$ & $\begin{array}{l}\text { National Oceans Office, workshop to assess user needs, and } \\
\text { which organisations could play a role as providers } \\
\text { - Melbourne University marine cadastre project } \\
\text { - Australian Oceanographic Data Commission, Geoscience } \\
\text { Australia, ANZLIC, CSIRO, } \\
\text { several web portals - Australian hydrographic service, oceans } \\
\text { portal, on-line atlas for each state, CSIRO merlin data portal, } \\
\text { ERIN } \\
\text { bathymetry, cadastre, wave and tide data, seagrass } \\
\text { Australia's marine science and technology plan } \\
\text { marineXML, have developed national standards for terrestrial data } \\
\text { ICSM }\end{array}$ \\
\hline Ireland & $\begin{array}{l}\text { SDI: } \\
\text { Access: }\end{array}$ & $\begin{array}{l}\text { includes marine spatial data in definition for NSDI, but ISDI is } \\
\text { still at ‘vision’ stage } \\
\text { Marine Irish Digital Atlas (MIDA) ‘improve access to coastal } \\
\text { data by offering a web GIS-based portal’ [20] }\end{array}$ \\
\hline $\begin{array}{l}\text { New } \\
\text { Zealand }\end{array}$ & $\begin{array}{l}\text { Marine Cad } \\
\text { Policy: }\end{array}$ & $\begin{array}{l}\text { e: 'A marine cadastre is a system to enable the boundaries of } \\
\text { maritime rights and interest to be recorded, spatially } \\
\text { managed and physically defined in relationship to the } \\
\text { boundaries of other neighbouring or underlying rights and } \\
\text { interests' [21] } \\
\text { Nineteen principles for development of 'seabed cadastre' covering } \\
\text { scope, design, boundaries, geodetic datums, and regulation [22] }\end{array}$ \\
\hline $\begin{array}{l}\text { United } \\
\text { Kingdom }\end{array}$ & Marine Spa & $\begin{array}{l}\text { Planning: 'a strategic plan for regulating, managing, and protecting } \\
\text { the marine environment that addresses the multiple, cumulative } \\
\text { and potentially conflicting uses of the sea' [23] }\end{array}$ \\
\hline Global level & $\begin{array}{l}\text { People: } \\
\text { Access: }\end{array}$ & $\begin{array}{l}\text { GSDI is a global and open process for coordinating the } \\
\text { organisation, management and use of geospatial data and related } \\
\text { activities. It encompasses the policies, organisational remits, data, } \\
\text { technologies, standards, delivery mechanisms, and financial and } \\
\text { human resources necessary to ensure that those working at the } \\
\text { global and regional scale are not impeded in meeting their } \\
\text { objectives [24] } \\
\text { Intergovernmental Oceanographic Commission Committee on } \\
\text { International Oceanographic Data and Information Exchange } \\
\text { IOC/ IODE } \\
\text { IOC/IODE Oceans portal - data discovery catalogue } \\
\text { IODE 'facilitate the exchange of oceanographic data and } \\
\text { information' } \\
\text { Provides a link to all member states marine data directories or } \\
\text { portals } \\
\text { See: http://ioc.unesco.org /iode } \\
\text { Ocean Biogeographic Information Service (OBIS) - global geo- } \\
\text { referenced information on marine species } \\
\text { IOC marineXML consortium, } \\
\text { Global Ocean Observing System (GOOS), started with physical } \\
\text { data ie/ ocean temperatures, currents, tides, later biological and } \\
\text { chemical data }\end{array}$ \\
\hline $\begin{array}{l}\text { Asia-Pacific } \\
\text { Region }\end{array}$ & $\begin{array}{l}\text { APSDI: } \\
\text { Marine Cad }\end{array}$ & $\begin{array}{l}\text { (Asia-Pacific SDI) 'a network of databases, located throughout } \\
\text { the region, that together provide the fundamental data needed to } \\
\text { achieve the region's economic, social, human resources } \\
\text { development and environmental objectives' [25] } \\
\text { : 'a management tool, which spatially describes, visualises and } \\
\text { realises formally and informally defined rights, restrictions and }\end{array}$ \\
\hline
\end{tabular}




\begin{tabular}{|l|ll|}
\hline & & $\begin{array}{l}\text { responsibilities in the marine environment as a data layer in a } \\
\text { marine SDI, allowing them to be more effectively identified, } \\
\text { administered and accessed' [10] } \\
\text { includes the shoreline/ coastline }\end{array}$ \\
\hline Europe & INSPIRE: & $\begin{array}{l}\text { (Infrastructure for Spatial Information in Europe) aims at making } \\
\text { available relevant, harmonised and quality geographic } \\
\text { information for the purpose of formulation, implementation, } \\
\text { monitoring and evaluation of Community policy-making [26] } \\
\text { includes bathymetry, coastline, oceanographic spatial features, sea } \\
\text { regions, fishery resources, aquaculture facilities }\end{array}$ \\
\hline Data: & &
\end{tabular}

Table 1: Practical Examples of Marine Administration around the world

Table 1 shows that some countries are beginning to consider marine administration and are using spatial data management to improve decision-making and management in their offshore environments. Each country is approaching this idea with its own perspective and has developed slightly different methods to improve their marine management using spatial data management tools. Global, regional and national effort to improve access and sharing of marine spatial data is occurring, there is now need for cooperation and collaboration between these efforts. This next section discusses some of these initiatives in more detail (also see [27], [28], [29] for other examples)

\section{1) Australia - ARC Marine Cadastre Project}

In response to the issues described above a two year research project commenced in mid-2002 and was completed in July 2004. This project aimed to define the concept of a marine cadastre. It was funded by the Australian Research Council (ARC) and was supported by The Department of Natural Resources and Mines, Land Victoria and Geoscience Australia. There were two research aspects to the project, one focused on the similarities and differences between the existing land cadastre and a future marine cadastre. The second looked at issues of 3D and 4D parcel definition, the application of uncertainty in maritime boundary delimitation and coastline definition, and the integration of uncertainty within a multi-dimensional cadastral object model.

Following the success of the first ARC Marine Cadastre project a new ARC grant was awarded in July 2004 to run until July 2006 for a second project on 'Addressing key scientific and policy issues for an Australian marine cadastre, and includes industry 
partners: Department of Land Administration Western Australia (WA), Department of Lands New South Wales (NSW) and Land Information New Zealand. There are four research areas within this project:

1. Resolving issues in the definition of the tidal interface

2. The use of natural rather than artificial boundaries in a marine cadastre

3. Extension and application of the ASDI to include a marine dimension

4. Marine policy, legal and security issues

More information can be found at www.geom.unimelb.edu.au/maritime/index.htm

A marine cadastre has been recognised, in Australia as well as internationally, as a fundamental offshore dataset. In Australia it will essentially provide an ability to define, manage and administrate boundaries and their associated rights, restrictions and responsibilities in the marine environment, as an important layer in a marine SDI. This is well understood by all participants in the ARC project. The overall aim of this project is the policy and technical basis upon which a marine cadastre can be built. Each research area aims to provide one aspect, the boundaries, the coordination of spatial data or the legal, policy and security implications. It is believed that these areas represent current major impediments to an Australian marine cadastre. The end result of the project will be to facilitate the development of a marine SDI and a marine cadastre in Australia.

\section{2) The Global Oceans Observing System}

Chapter 40 of Agenda 21: from the United Nations Conference on Environment and Development, recommended improved methods of data collection, analysis, dissemination, use and sharing, to promote a better understanding of our Earth and its environmental processes [30]. In response the United Nations has proposed three separate Global Observing systems, the Global Terrestrial Observing System (GTOS), the Global Oceans Observing System (GOOS) and the Global Climate Observing System (GCOS). These observing systems are being implemented to improve availability of general scientific data, through better networking of existing data collection systems. For example the GOOS aims to establish a global reporting and assessment of the state of the marine environment. It is building on existing ocean observations systems, for example the Voluntary Observing Ship (VOS) program that 
takes meteorological observations, and tide data from the global sea level observing system. The primary output of GOOS is global or basin scale datasets at real or near real time [31], and it is currently focussed on physical data such as sea surface temperatures, currents and salinity observations.

The main challenge that GOOS faces is in data coordination and harmonisation of observations to improve interoperability between all possible users [32]. It aims to comply with existing national and international standards, and information systems using open technologies and standards. Looking at GOOS through the SDI components, it can be seen that while the data component of GOOS is well developed and researched, the backend infrastructure, particularly the standards and policies still needs some work. With issues such as spatial data coordination highlighted at presentations from CZAP [32], the need for common standards, policies and technology is evident. GOOS is described as a 'shared observation network' [33], and as such has similar aims to a global SDI - sharing spatial data on a global scale. The joint committee of management is promoting communication and networking between separate GOOS projects - Indian Ocean GOOS, Coastal GOOS etc. This involves integrating existing systems and promoting the use of similar standards and technology to allow interoperability on a regional and global scale. The aim is for one system that contains fundamental datasets - bathymetry, sea surface currents, wave height etc - covering the oceans.

\section{3) Irish Sea Project - Marine Spatial Planning}

A pilot project in the Irish Sea involving England, Ireland, Northern Ireland, Scotland Wales and the Isle of Man, aims to improve management of this area by developing spatial planning. Tyldesley [21] describes marine spatial planning as including planmaking, implementation, enforcement, monitoring and performance review. The spatial component of the plans comes from the recommendation that the plans include the physical and spatial dimension of all management strategies, plans, uses, resources, and legislation. This is to promote better understanding of the area and thus better decision-making and planning. 
The marine spatial planning concept is similar to the marine cadastre concept in that marine spatial planning aims to promote more integrated planning of uses, rights, interests and restrictions in the marine environment by having them spatially defined. This is similar to the aim of the marine cadastre in the Australian example above, which is to 'describe, visualise and realise rights, restrictions and responsibilities in the marine environment'. The main challenge highlighted with marine spatial planning in the Irish sea are the disjointed approach to managing the coastal zone, with different planning systems operating on either side of the coastline. It was recognised that management should cover the whole jurisdiction of a country. However this also raises other issues in the Irish Sea, as this area is shared by five countries, but shouldn’t be managed by five different governance systems [34]. Therefore an integrated approach is suggested, and being tested in this pilot project. Also similar to the Australian project the Irish Sea pilot project recommends that access to spatial data and information should form an integral part of marine spatial planning. While the idea of a marine SDI is not mentioned, Tyldesley [21] states that currently there is 'no coordination of geographic information or other mapping systems to collate, interpret, and use information or to form a basis for spatial planning at sea'. There are marine SDI initiatives underway in Ireland and the UK (see table 1), but these are currently in the vision stage, and not part of Irish Sea pilot project.

\section{4) Ocean Portals - Australia, Ireland, Global}

Internet portals/ clearinghouses/ warehouses are developing around the World that intend to be a source of marine and/or coastal spatial data and information. For example there are several in Australia: the Oceans Portal proposed by the Australian National Oceans Office (NOO), Geoscience Australia’s Australian Marine Boundaries Information Systems (AMBIS), and CSIRO’s marine data directory Marlin. In Ireland the Marine Irish Digital Atlas aims to be a 'single source for marine and coastal geospatial information in Ireland' [35]. There are other examples at National and State levels in the USA, France and many other countries [35]. Global level oceans portals are developing too, such as the Oceans Biogeographic Information System (OBIS) - a virtual repository of oceanographic and biogeographic information. 
These initiatives are all examples of possible access-networks in an SDI, delivering front-end access to data through an Internet portal. There are many different examples of these, most developed to support decision-making for a particular discipline or location through better access to spatial data. These would make-up one part of the SDI, with the rest being the back-end infrastructure such as the standards, policies and technologies. The main difference between these and an SDI is that most of these portals only focus on providing data and information. However the data will only be useful if it is compatible with the potential users system. Therefore the clearinghouse or access network needs to be linked with the other SDI components (people, data, standards and policy) so that data is accessible and also usable [36]. Some portals have recognised this, for example the Australian Oceans Portal suggests using Open GIS Consortium (OGC) standards and technology to comply with international and national standards as recommended by ANZLIC for the ASDI [37]. This would make the spatial data interoperable allowing many different people to use the same data. This is based on existing research into SDI that, until recently, has mainly been applied to land-related spatial data (as discussed above). Research is now needed to see if these ideas are as applicable to sharing marine and coastal spatial data. Existing oceans portals can take advantage of this research to enable them to provide more interoperable and useful spatial data by using the SDI concepts, components and hierarchy.

\section{Applying SDI to the Marine Environment}

The SDI concept has until recently only been used to describe land related spatial data and information. While these concepts might be applicable and desirable to improve marine administration, the nature, definition and components need to be examined and tested for their ability to describe marine and coastal spatial data and information. This section examines each component of SDI (data, standards, policies, access networks and people) and discusses its applicability to the marine environment

\section{Data}

The marine environment is dynamic and multi-dimensional, providing a more difficult area for data collection and updating. Data is usually collected on a project- 
based approach and is rarely shared between different organisations. A key issue is the availability of data. There is a substantial amount of data collected about the marine and coastal environments, but it is often not available to all users. The other issue is that if it is available, it may not be interoperable. To partially resolve this problem in the land environment often an SDI will include 'fundamental datasets', those that will be needed to support most business processes, with a designated custodian responsible for maintaining them. For example the SDI for the State of Victoria, Australia has geodetic control, cadastral, address, transport, administrative boundaries, elevation, hydrography and imagery fundamental datasets. Suggestions for fundamental datasets offshore include: bathymetry, marine protected areas, political boundaries, oceanography, sea level, waves, water quality, sea floor composition, meteorological conditions, and biodiversity regionalisation [6]. In the USA NSDI bathymetry is a sub-layer of the elevation fundamental dataset [25]. This may be possible for other datasets, however it is likely there will be some that will be regarded as fundamental only in the marine environment (ie salinity, waves, water quality). Interoperability is an important part of sharing spatial data in an SDI [38]. The differences in the marine and terrestrial environments in fundamental datasets, data collection and technology used in these environments will make interoperability between marine and terrestrial spatial data a big challenge.

\section{Standards}

Standards specify regulations for data access, content, and exchange [37]. Standards are used to ensure interoperability and integratability of different datasets. In the terrestrial environment there are many different standards used, often set at international and national levels. The International Standards Organisation Technical Committee 211 (ISO TC/211) has recently developed a set of 40 Geographic Information related standards most of which are focussed on terrestrial spatial data. In the marine environment the International Hydrographic Organisation (IHO) in conjunction with the International Hydrographic Bureau have developed a transfer standard for digital hydrographic data (S-57) and are examining other standards for marine data. These standards, however, are not at the same level of completeness as the ISO TC/211 standards. The main issue is that if different standards need to be developed for marine spatial data exchange this will limit the interoperability between 
marine and terrestrial spatial data. It also creates confusion in the coastal zone as to which standard should be applied.

Another initiative that aims for interoperability between datasets from different custodians is the development of Extensible Markup Language (XML). XML is an exchange data format that is used on the Internet and has been described as 'the building blocks that house data’ [39]. There are several projects around the world examining the creation of a marine specific XML. The International Oceans Commission (IOC) has established a Marine XML consortium, which is looking at developing an international standard form of marineXML. Standardisation at an international level is required for interoperability on a global and regional level, otherwise marineXML will become 'just another data format' [40]. The main benefit of using XML is that it provides a common format to store data, and so allows data to be exchanged easily between providers, value adders, and users. Marine XML is being developed and used by the Australian Oceanographic Data Centre to encode their marine data for storage and exchange [40].

\section{Policies}

Policies are influenced by international best practice in spatial data management and exchange. Marine data management policies are developing in Australia and the USA (see table 1). In the United States NOAA Coastal Service Centre has developed a policy for Coastal NSDI that aims to link the coastal management community with the National SDI. Australia's Marine Science and Technology plan sets out policy for marine spatial data sharing and management. The policy includes: avoiding duplication, data consistency, improved access to data and coordinated data management [41].

The current ASDI policies cover access, data custodianship, conformity, quality, content, industry engagement, avoidance of duplication and sensitivity [42]. In applying these policies for terrestrial spatial data to the marine and coastal environments it is likely there will be differences in terms of data quality, data access and privacy. Data quality depends on collection, completeness, currency, reliability etc. and due to the complexity of the marine environment and the different technologies used for data collection, may be more difficult to achieve at the same 
level as terrestrial data. Fixed line data transfer supports data access onshore. In the marine environment there may need to be the capability for wireless data transfer, for people accessing or uploading data offshore. Privacy over spatial data in the marine environment is a concern with many countries reluctant to share spatial information relating to their marine jurisdictions, and as such there may need to be different privacy policies for offshore data [27].

\section{Access Networks}

In a questionnaire conducted by the University of Melbourne ARC Marine Cadastre group one of the main issues highlighted was accessibility of data and metadata [5]. Access networks usually comprise data warehouses, data portals, one-stop shops, online atlases or similar. Around the world these are being set up to facilitate access to marine spatial data. For example in Australia, the National Oceans Office is developing an oceans portal, data is accessible through the Australian Oceanographic Data Centre (AODC) and each state has an offshore atlas, as an online GIS, that combines mapping capabilities and a link to metadata. For these access network to support interoperable and coordinated data they must comply with the standards and policies specified by the SDI. An issue highlighted in the 'Policies' section is the ability of someone offshore being able to access data. For example bathymetry for navigation, the rights and restrictions attached to a particular location, or sea surface temperatures or currents in a search and rescue operation. The technology that allows data transfer and access onshore, will not be appropriate for use offshore, and so alternatives, such as wireless data transfer will be needed.

\section{People and Partnerships}

This component is one of the most important components of SDI. The people in SDI are the data providers, value-adders and data users. In the marine environment these people will come from private industries such as shipping, defence, aquaculture and conservation, as well as from government at local, state and national levels. There will already be some degree of spatial data management that is occurring within these groups, even if only within or between organisations. It is important that this is recognised and can be built upon for the SDI to be relevant to those who will use it. This data management will also need to be integrated with the standards and policies that are set at global, regional and national levels. Both Binns [28] and ANZLIC [43] 
have reported that a barrier to SDI development and marine SDI development is 'immature institutional arrangements' and the reluctance of many organisations to share their data. Therefore a challenge in developing a marine SDI will be in encouraging cooperation and a culture for spatial data sharing between the institutions involved in marine and coastal spatial data collection and use [44]. Underlying these issues is the need for an institutional framework that will support marine SDI development, and impose responsibility for organising and building the SDI.

The key to success in SDI initiatives is partnerships within and between organisations involved in marine administration and spatial information. Multiple reports internationally have highlighted the need for better coordination and integration between and within levels of government to improve coastal zone management [45], [46]. Partnerships drive the development of SDI, allowing people to work together to achieve their respective goals. In the marine environment it is likely that there are existing partnerships between or within organisations. It is important that these are recognised as they can be built upon to facilitate the development of Marine SDI.

\section{The Coastal Zone}

Until this point this paper has discussed marine and coastal SDI development as occurring separately from the existing land-focussed SDIs. Overlying this, there is much debate over whether these environments should be managed and administrated as one or as separate areas. Current research into marine and coastal zone management highlights the need for a holistic and integrated approach to management of these areas [27], [47], and this is the main goal behind ICZM. Thus the need to effectively manage the coastal zone as well as the need for integration of data between the three environments (land, coast, marine) requires a management system that incorporates them all. Currently many countries have a land administration system and some kind of marine administration system, but these operate as separate entities causing confusion and a lack of management at the coastal zone (Figure 5). 


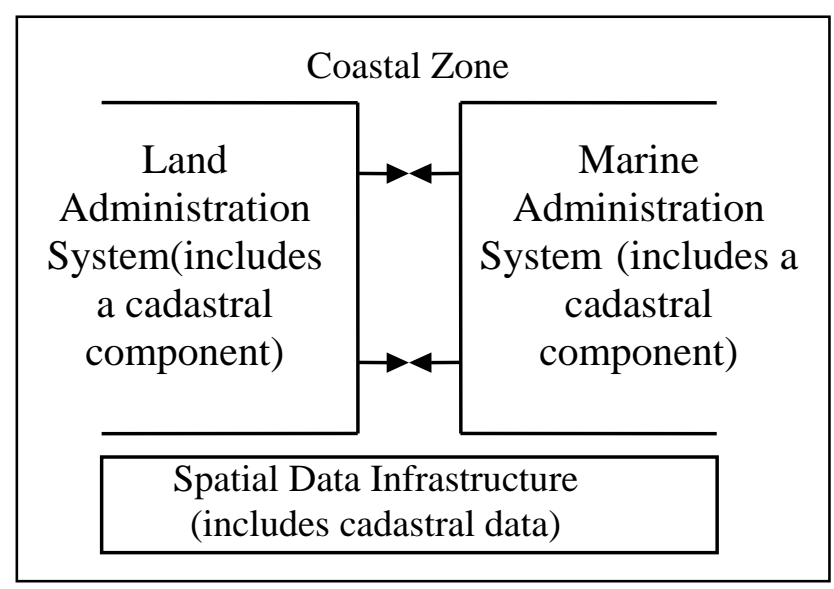

Figure 5: Combining Administration Systems [10]

A more integrated approach would be supported by the development of a seamless SDI. This would allow people involved in administering the areas access to interoperable data from all environments and thus strengthen the chance of more integrated management. If two separate SDIs were created it would deepen the gap between these two administration systems and make coastal zone management more difficult. There is an opportunity for more research to be conducted into combining these initiatives and developing a seamless SDI that can include spatial data from all environments. Using common SDI standards, policies and access networks can ensure that this spatial data is interoperable, facilitating the design of a seamless SDI and thus improving decision-making and administration in the coastal and marine environments.

\section{Conclusion}

Our increased use and improved understanding of the marine and coastal environments has lead to the realisation that we need better management and administration systems to deal with these areas. SDI is an initiative that allows access and sharing of spatial data for decision-making, management and administration. In the terrestrial environment SDI is developing to improve coordination and sharing of land related datasets. Developing a seamless SDI that can include data from the land, coast and marine environments will improve access and sharing of data between these environments. The ability to access and integrate data has been identified as a problem by people involved in coastal zone management, as can be seen from the 
development of ICM initiatives. This paper highlights the potential for using SDI standards, policies and access networks to improve access to spatial data in the marine and coastal environments. At the moment the practical implementation of a marine SDI is mainly occurring separately to the terrestrial SDI, using the same components but adapting them to suit the different environment. Research now needs to focus on combining these initiatives and developing a seamless SDI. Based on this need there is ongoing research, as noted above, into the policy and technical aspect of marine administration, with an overall goal of improving decision-making and administration in the coastal and marine environments.

\section{Acknowledgements}

The authors would like to acknowledge the support of the University of Melbourne, Department of Sustainability and Environment, Geoscience Australia, Department of Land Administration WA, Department of Lands NSW, Land Information New Zealand, The Australian Research Council (ARC) and members of The Marine Cadastre Research Group and The Centre for SDIs and Land Administration at the Department of Geomatics, the University of Melbourne. However, the views expressed in the paper are those of the authors and do not reflect the views of these groups.

\section{References}

[1] Ting, L. and Williamson I.P. Spatial Data Infrastructures and Good Governance: Frameworks for Land Administration Reform to Support Sustainable Development. 4th Global Spatial Data Infrastructure Conference, Cape Town, South Africa. 2000.

[2] Mitchell, D. J., Collier P. A., et al. The United Nations Convention on the Law of the Sea and the Delimitation of Australia's Maritime Boundaries. Trans Tasman Surveyor 2001; 4: 50-57.

[3] Thia-Eng, C., Bernad, S., et al. Coastal and Ocean Governance of the Seas of East Asia: Towards an Era of New Regional Cooperation and Partnerships. Tropical Coasts 2003; 10 (1): 46-55.

[4] Doody, J.P. Information Required for Integrated Coastal Zone Management: Conclusions from the European Demonstration Programme. Coastal Management 30 (2) : 163-173 2003 
[5] Forse, J.E. and Collier, P.A. Assessing the Need for an Australian Marine Cadastre. Coastal GIS Workshop, Wollongong, New South Wales, 7-8 July 2003

[6] CSIRO 'National Marine Data Policy’, CSIRO Marine Data Centre. Available at www.marine.csiro.au/datacentre/forums/nat_policy.htm accessed on 27/07/04

[7] Binns, A., Fraser, R. Industry Consultation (Qld, Vic, National) Presented at Marine Cadastre Seminar, Department of Geomatics, University of Melbourne, Australia. 2004

[8] Killpack, D. Integrating Spatial Technologies within the Coastal Zone Management Programs of the U.S. Flag Pacific States. Coastal Zone Asia Pacific Conference, Brisbane, Australia 2004.

[9] Sitaniapessy, M.J., Sri Hartini, and Suprejaka. Establishment of Spatial Data Supporting the Development of Sumba Island East Nusa Tenggara - Indonesia. Coastal Zone Asia Pacific Conference, Brisbane, Australia 2004.

[10] UN-PCGIAP Working Group 3. Report on the International Workshop on Administrating the Marine Environment - The Spatial Dimension. Kuala Lumper, Malaysia, May 4-7, 2004

[11] Rajabifard, A., and Williamson, I.P. Regional SDI Development - A Fundamental Framework. Journal of Geospatial Today, Vol. 2, Issue 5, India. 2004

[12] FGDC. Framework, Introduction and Guide. (Washington, Federal Geographic Data Committee) 1997

[13] Rajabifard, A., Feeney, M., and Williamson I.P. Future Directions for the Development of Spatial Data Infrastructure. Journal of the International Institute for Aerospace Survey and Earth Sciences ITC 2002; Vol. 4, No. 1, pp. 11-22

[14] Borrero S. Case Studies in Interdisciplinary Coordination. In: GSDI Cookbook v2.0. Edited by: M. Reichardt. Chapter 9, pp: 119-148 2004 Available at http://www.gsdi.org/docs2004/Cookbook/cookbookV2.0.pdf accessed 06/01/05

[15] DFO. Marine User Requirements for Geospatial Data: Summary 2001.' Geospatial Projects Integration Office, (Ottawa, Canada: Department of Fisheries and Oceans 2001)

http://www.geoconnections.org/CGDI.cfm/fuseaction/keyDocs.home/gcs.cfm accessed on: 25/05/04

[16] Ng'ang'a, S., Sutherland, M., Nichols, S. Data Integration and Visualisation Requirements for a Canadian Marine Cadastre: Lessons from the Proposed Musquash Marine Protected Area. Symposium on Geospatial Theory, Processing and Applications, Ottawa 2002

[17] Fowler, C., Treml, E. Building a Marine Cadastral Information System for the United States - a Case Study. International Journal on Computers, Environment \& Urban Systems Special Issues: Cadastral Systems 2001; 24 (4-5) 493-507 
[18] Finney, K., Mosbauer, A. An Oceans Portal Accessing Distributed Bioregionalisation Related Datasets Through a National Marine Registry. National Oceans Office 2003, available at:

http://www.oceans.gov.au/pdf/PortalRequirments.pdf accessed on: 13/07/04

[19] Todd, P. Synchronising the Law and Maps - A Web Based Solution. $5^{\text {th }}$

Conference on Computerisation of Law via the Internet Sydney, Australia. 2003

[20] O’Dea, L., Cummins, V., Dwyer, N. Developing an International Web Portal for Coastal Data in Ireland: Data Issues in the Marine Irish Digital Atlas. Presented at Oceanology International: GIS in the Marine and Coastal Environment Conference, London. 2004

[21] Robertson, B., Benwell G., Hoogsteden, C. The Marine Resource:

Administration Infrastructure Requirements. UN-FIG Conference on Land Tenure and Cadastral Infrastructures for Sustainable Development, Melbourne, Australia 1999

[22] Grant, D. Principles for a Seabed Cadastre. New Zealand Institute of Surveyors Conference and AGM, FIG Commission VIII Conference. Bay of Islands, New Zealand 1999

[23] Tyldesley, D. Coastal and Marine Spatial Planning Framework for the Irish Sea Pilot Project. Defra 2004

[24] GSDI. Global Spatial Data Infrastructure Newsletter January 2004 Available at http://www.gsdi.org/docs2004/GSDI_Newsletter-v3.pdf, accessed on 11/08/04

[25] PCGIAP. A Spatial Data Infrastructure for the Asia and the Pacific Region. Permanent Committee on GIS Infrastructure for the Asia and the Pacific 1998, PCGIAP Publication No.1

[26] Ryttersgaard, J. Across Boundaries - SDI in an European Perspective. FIG Working Week Athens, Greece. 2004

[27] Bartlett, D., Longhorn R., et al. Marine and Coastal Data Infrastructures: a missing piece in the SDI puzzle. 7th Global Spatial Data Infrastructure conference, Bangalore, India. 2004

[28] Binns, A. Defining a Marine Cadastre: Legal and Institutional Aspects. M.Sc Thesis, The University of Melbourne, Australia 2004

[29] Longhorn, R. Coastal Spatial Data Infrastructure as part of National/ Regional SDI. CoastGIS’03 Genova, Italy 2003

[30] UN. Agenda 21. United Nations Division for Sustainable Development, 1992 Available at http://www.un.org/esa/sustdev/agenda21text.htm, accessed on 15 January 2005 
[32] Le Tissier. M., and Kremer, H. Scientific Approaches for Integrated Management of coastal Zones and Water (Challenging Future Earth Science to Bridge Across Multiple Interfaces of Global Coasts - A Perspective from the New LOICZ Programme) Coastal Zone Asia Pacific Conference, Brisbane, QLD 2004

[33] Bernal P. The role of Global Observing Systems in Sustainable Development: Helping Nations Manage Societies, Economics and Environments. Presented at UNEP, Paris 2002

[34] CMS. Spatial Planning in the Coastal and Marine Environment: Next Steps to Action. Coastal Management for Sustainability. CoastNET Conference 2003

[35] Dwyer, N., O’Dea, L., et al. The Marine Irish Digital Atlas: A Web Portal to Coastal and Marine Data in Ireland.

[36] Crompvoets, J., Bregt, A., Rajabifard, A., Williamson, I.P. Assessing the Worldwide Developments of National Spatial Data Clearinghouses. Geographical Information Science 200418 (7) pp: 665-689

[37] ANZLIC. Geographic Information Standards. 2002 Available at http://www.anzlic.org.au/publications.html accessed on 29/06/04

[38] Smith, J., Kealy, A. SDI and Location Based Wireless Applications. In: Developing Spatial Data Infrastructures: From concept to reality. Edited by: I. P. Williamson, A. Rajabifard and M.E. F. Feeney, Taylor and Francis, London 2003 Ch. 16 pp: 263-279

[39] Keeley, R., Isenor, A., Linguanti, J. XML Bricks Available at http://ioc.unesco.org/marinexml/files.php accessed on 18/06/04

[40] Ronai, B., Sliogeris, P., De Plater, M., Jankowska, K. Development and Use of Marine XML within the Australian Oceanographic Data Centre to Encapsulate Marine Data. Marine Data Exchange Systems Conference, Helsinki, Finland. 2002

[41] National Oceans Office 'Australia’s Marine Science and Technology Plan’ Available at: http://www.oceans.gov.au/marine_science_tec_plan/mstplan.pdf accessed on 27/09/04

[42] ANZLIC Policy Statement on Spatial Data Management. 1999 Available at: http://www.anzlic.org.au/publications.html accessed on 06/07/04

[43] ANZLIC Implementing the Australian Spatial Data Infrastructure. ANZLIC Spatial Data Infrastructure Standing Committee 2003, available at http://www.anzlic.org.au/publications.html accessed on 29/06/04

[44] Rajabifard, A., Williamson, I.P. Anticipating the Cultural Aspects of Sharing for SDI Development. Spatial Sciences Conference, Canberra, Australia 2003 
[45] Hudson, K., and Smith, T. The Art of Juggling and Coastal Zone Management: Keeping Multiple Spheres of Government in the Loop. Coastal Zone Asia Pacific Conference, Bangkok, Thailand 2002

[46] Middle, G. Institutional arrangements, incentives and governance - Unlocking the barriers to successful coastal policy making. Coast to Coast 2002, Gold Coast, Australia 2004

[47] Wescott, G. The Theory and Practice of Coastal Area Planning: Linking Strategic Planning to Local Communities. Coastal Management 2004; 32: 95-100. 


\section{University Library}

\section{- M M N E R VA A gateway to Melbourne's research publications}

Minerva Access is the Institutional Repository of The University of Melbourne

Author/s:

Strain, L;Rajabifard, A;Williamson, I

Title:

Marine administration and spatial data infrastructure

Date:

2006-07-01

Citation:

Strain, L., Rajabifard, A. \& Williamson, I. (2006). Marine administration and spatial data infrastructure. MARINE POLICY, 30 (4), pp.431-441. https://doi.org/10.1016/ j.marpol.2005.03.005.

Publication Status:

Published

Persistent Link:

http://hdl.handle.net/11343/34917 